\title{
Effect Of Organizational Culture On Organizational Commitment And Nurse Involvement As Intervening Variable: Study At Maternity Hospital Business In Pekanbaru City, Indonesia
}

\author{
Kasmiruddin $^{1 *}$, Meyzi Heriyanto ${ }^{2}$, Hernimawarti $^{3}$ \\ ${ }^{1,2}$ Department of Business Administration, University of Riau \\ ${ }^{3}$ Department of Public Administration, Lancang Kuning University \\ *Corresponding author: \\ Email: kasmiruddin@lecturer.unri.ac.id
}

\begin{abstract}
This study aims to prove the indirect effect of organizational culture on organizational commitment through the involvement of nurses in the Maternity Hospital, and whether the effect is greater than the direct effect. This study uses a quantitative approach with explanatory and primary data. Collecting data using a questionnaire with a research sample of 67 nurses. This study uses PLS-SEM with Smart-PLS software in analyzing and processing data. The results showed that organizational culture had a direct effect on organizational commitment, organizational culture had an effect on nurse involvement in hospitals, and nurse involvement had an effect on organizational commitment. However, it was found that organizational culture was not proven to have an effect on commitment through the nurse involvement variable, based on indirect testing. Therefore, the nurse's involvement variable has not shown its contribution in improving organizational culture and commitment while working at the hospital.
\end{abstract}

Keywords: Organizational Culture, Organizational Commitment, Nurse Involvement, Maternity Hospital.

\section{INTRODUCTION}

Substantially, the ability and quality of work of an employee in a company is a necessity in order to realize the continuity of company life. In today's global era, quality resources are increasingly needed to win an increasingly complex and dynamic business competition. Qualified employees are expected to be able to improve performance and service quality so that the company's customers can be maintained and even expected to increase the number of loyal customers to the company. Changes that occur in the business environment, such as consumers, competitors, suppliers of capital or materials as well as political and economic conditions, lead companies to make changes and improve the quality of human resources, so that they are responsive to changes that occur. No matter how great the business competition is, it will be easy for the company to anticipate if it has the advantage of quality resources and in accordance with the needs of the environment.

Quality resources are the embodiment or implementation of employee attitudes and behavior of employees , meaning that employees who have a good behavior in the company of "professional" will usually result in quality or good performance. Employee behavior describes how the attitude or morality of employees in carrying out work in the organization (Robbins and Judge, 2013). Thus, to create a competitive advantage in terms of the quality of human resources, the company needs to generate positive employee attitudes towards work, including employees must have commitment and involvement with the company, in order to have a competitive advantage. In the face of competition that continues to experience changes in an increasingly complex and dynamic direction, it is natural for entrepreneurs to carry out various strategies to anticipate competition and be able to maintain company performance, namely making changes and improving service quality. Companies that can win business competition are companies that are able to find and create competitive 
advantages, namely having different products and or service quality advantages. Even though the company already has professionalism in its work, it still needs to increase a positive attitude towards work, including employees must have a commitment to the organization, so that service quality has a competitive advantage.

Organizational commitment is one of the important attitudes and behavior that created a leader in the organization, attitude determines the success of organizational commitment's organizations realize the achievement of objectives, namely improving the performance of employees and organizations. Employees who have high organizational commitment are expected to continue to maintain and improve the quality of the resulting performance so that the company can realize organizational performance. Mowday et al., (1979) say employees who have high organizational commitment will be more motivated to attend the organization and try to achieve organizational goals. Employees who have high organizational commitment are expected to continue to maintain and improve the quality of the resulting performance so that the company can realize organizational performance. committed employees will be an added advantage for the organization (Stella, 2012) According to Morrison (1997), organizational commitment is very important for an organization ujtuk lower levels of desire of employees out of the company and its employees are committed to tend to expend greater effort on pekeraannya.

According to Greenberg \& Baron cited by Gamayuni, (2019), employees who have high organizational commitment are more stable, productive and more profitable for the organization. Robbins (2006) reveals that organizational commitment shows the alignment of employees towards the organization and the desire to survive in the organization, employees who have high organizational commitment tend to side with the organization that recruits the employee.Efforts to increase employee organizational commitment need to be carried out by the company in order to accelerate the creation of a positive and loyal attitude towards the organization. Of course, the efforts that will be made are expected to arouse the desire of employees by devoting their optimal abilities for the benefit of the organization. This is a challenge for companies to form and create higher employee organizational commitment so that business continuity is maintained. In contrast, low employee commitment has a negative impact onemployee and organizational performance. Employees who have low organizational commitment will make it difficult for companies to make changes and business development because they are not supported by employee attitudes and behavior.

An internal factor that can be used by leaders to increase employee organizational commitment is the application of organizational culture which is also very important in understanding organizational behavior. Organizational culture involves standards and norms that govern how employees should behave in a particular organization. Therefore, managers and employees or all members of the organization can behave well, because all members are regulated and directed by the organizational culture (Manetje \& Martins, 2009). The strength of organizational culture has a strong influence on employee behavior and attitudes. Previously, Meyer \& Allen (1991) have explained that organizational culture acts as an antecedent of organizational commitment. The research findings of O'Reilly et al., (1991) conclude that employees who work in a strong organizational culture feel more committed to the organization than a weak organizational culture.

Lok \& Crawford (1999) put more emphasis on research on innovative and supportive subcultures that have a significant and positive influence on employee organizational commitment. Kartiningsih (2007) and Mahayasa (2018) have proven that there is a relationship between organizational culture and employee organizational commitment. Jigjiddorj et al., (2021), organizations with a strong culture are better able to retain employees who are highly committed to their work and organization.In addition to organizational culture as a factor that affects the level of employee organizational commitment is employee involvement in the organization. Employee involvement is a process of work participation in realizing organizational success. Robbins (2006) said that employee involvement can have a very large influence on the success of a company in achieving goals, including the low desire of employees to 
leave and the acquisition of higher profits. Employees who have high involvement tend to use maximum capacity to encourage increased employee organizational commitment for organizational success. Study by Rameshkumar (2020) revealed that the employee involvement variable was significantly proven as an antecedent factor of organizational commitment. Indayati (2012) have shown that employee involvement can increase employee organizational commitment. Research by Indayati (2012), Pawestri \& Pradhanawati (2018) and Sutiyem et al., (2020) found a significant effect of employee engagement on organizational commitment.

The results study by Akbar (2013) shows that regarding the influence of organizational culture on employee engagement, the stronger the organizational culture, the higher the level of employee engagement. Building a strong culture is very much needed by the company to generate and increase employee involvement in work, high employee involvement is the result of an effective corporate culture (Nurcholis, G., \& Budi, 2019). In a company, the application of organizational culture is a factor needed to increase employee involvement in work in the company (Macey \& Schneider, 2008; Kalia \& Verma, 2017; Lockwood, 2007). In a study conducted by Fanggidae et al., (2020) it has also been proven that there is a significant influence of organizational culture on employee engagement with insurance companies. So this study tries to prove the indirect effect of culture on organizational commitment with the involvement of nurses as the intervening variable.

\section{Literature Review}

\subsection{Organizational culture}

Martins \& Martins (2003) define organizational culture as "a system of shared meanings held by members, distinguishing an organization from other organizations to give each organization a distinct character. Luthans (2006), organizational culture are norms and values to direct the behavior of organizational members. Robbins (2006) says organizational culture is a system of shared meaning held by members that distinguishes the organization from other organizations. Vukonjanski \& Nikolic (2013), organizational culture is determined by the dominant values of the organization accepted by the majority of employees. Cultural organization with regard to the implementation of the agreed value together are used as guidelines for employees to display attitudes and behavior within the organization.

Accordingly, important it determines the vision and organizational values and identify appropriate behaviors to shape the culture and further develop outreach strategies and inculcate these values and behaviors throughout the organization (Manetje \& Martins, 2009).From the several definitions put forward, it can be concluded that the notion of organizational culture in this study is a set of norms or values that are accepted and shared by members of the organization as a guide to behavior and to solve problems faced by the organization. Organizational culture is used as the basis for shaping employee attitudes and behavior, according to Robbins (2006) attitudes that are in accordance with the interests and goals of the organization, namely organizational commitment, job satisfaction and work involvement in the organization.Organizational culture affects all aspects of business and life in an organization, of course this is related to the success of the organization creating a positive positive attitude towards the organization. Robbins (2006) states that organizational success in creating positive attitudes and behavior is determined by the strength or weakness of the organizational culture.

Organizational culture has a strong influence on the behavior and attitude of the employees. Organizational culture includes standards and norms that govern how employees should behave in a particular organization (Martins \& Martins, 2003). The opinion of Martins \& Martins (2003) and Robbins (2006) proves that a strong organizational culture has a strong influence significant impact on the behavior of organizational members. In other words, a strong culture is a powerful lever to guide behavior .Organizational culture, as a separate construct from societal culture, has been known to research for decades, and various

models can be found in various disciplines. In general, Dauber et al., (2012) stated that the three categories of 
approaches to the culture of the organization, namely a) the approach dimension, namely the approach is very focused on the empirical measurement of researchers, especially quantitative research, researchers and practitioners will find it easier to make better changes to organizational culture in terms of its dimensions. The relationship between these dimensions of organizational culture for the benefit of the organization lies in the management of culture that is carried out to make the organization more effective, namely organizational culture all may be associated with a variable dependent,b) the interrelated structure approach, and c) the typological approach, which is an approach that divides and combines organizations into certain categories. This dimensional approach is widely used by through changes to these dimensions.

According to Robbins (2006), the application of organizational culture implies the existence of certain dimensions or characteristics that are closely related and influence each other in the organization. Culture must be defined and measured, and if these dimensions are mixed and matched it will become the essence of an organizational culture, and act as a differentiator for organizational culture. These dimensions or characteristics, namely:

1) Innovation and the courage to take risks, show the extent to which employees are encouraged to be innovative and dare to take risks.

2) Attention to detail indicates an organizational culture characterized by an emphasis on accuracy and attention to detail.

3) Results-oriented, which describes a culture that emphasizes achievement, results, and action as important values.

4) People-oriented, meaning the extent to which management decisions take into account the effects of company results or performance on people in the company.

5) Oriented team, which means that culture is collaborative and emphasizes collaboration among employees.

6) Aggressive, namely culture appreciate aggressive competitiveness and beat the competitors; by emphasizing the value of this aggressiveness.

7) Stability, namely a rule-oriented and bureaucratic culture. When the environment is stable and certain, then this culture can help the organization to be effective by providing a stable and constant level of output.

\subsection{Employee Involvement}

Saks (2006) defines employee involvement as different and unique construction, consisting of components of cognitive, emotional, and behavioral employee berkaita $\mathrm{n}$ with a role in the organization. Macey \& Schneider (2008), employee involvement is the impact of one's understanding of initiative, effort, and persistence that leads to organizational goals. Schaufeli \& Bakker (2004) define employee engagement as positive, satisfied and work-related thinking that is characterized by passion, dedication, and absorption (vigor, dedication, and absorption).

Explicitly Robbins (2013) confirms employee engagement is closely related to a positive attitude to the work performed, namely the involvement of workers, satisfaction, and the enthusiasm of the work. Shuck \& Wollard (2010) say employee engagement is a condition of individual employee cognitive, emotional, and behavior that is directed to the desired organizational output. Employee engagement are identical with the dimensions of energy, involvement, and efficacy, and contrary to the dimensions of fatigue exhaustion, cynicism and ineffectiveness (Maslach et al., 2001). From the definition noted above, the notion keterlibayan workforce is associated with thinking and positive attitude of employees towards work that is manifested in the form of enthusiasm, pride and determination to carry out work. Employees who are highly involved have work enthusiasm and feel they have a close relationship with their company, and employees who are not involved 
in work are not optimal and have the potential to leave the company (Robbins, 2006). The concept of employee engagement is a concept that is widely discussed and studied by various researchers, this attitude is considered a factor that can build the emergence of various positive employee attitudes towards work. Employee engagement describe a state of mind, attitude and actions of the employees are in line with the wishes of the organization.

According to Macey \& Schneider (2008), the concept of engagement is widely used to refer to 3 dimensions, including trait engagement (the tendency to see the world as a place that has many advantages, namely proactive personality, positive influence and conscientiousness); psychological state engagement (the antecedents of behavioral engagement, such as satisfaction, involvement, commitment, empowerment) and behavioral engagement (adaptive behavior that can increase organizational effectiveness, including extra-role behavior, personal/proactive initiatives).The concept of employee engagement uses the concept proposed by Schaufeli \& Bakker (2004) to explain three dimensions of the concept of employee engagement, namely: a) vigor is an outpouring of energy and strong mentality during work, the courage to try hard to complete a job, and persevere in the face of work difficulties, b) dedication refers to being highly involved in the task and experiencing feelings of meaning, enthusiasm, inspiration, pride and challenge, c) absorption means that at work employees are always full of concentration and serious about a job. Individuals feel when he works time seems to pass so quickly and find it difficult to separate himself from work.

\subsection{Organizational Commitment}

Attitude is an important factor in organizations especially their attitude towards work. Therefore, attitudes can help company leaders to predict employee work behavior (Luthans, 2006). Attitudes related to work can produce positive or negative perceptions of aspects of the work environment, attitudes towards work including work involvement and organizational commitment (Robbins and Judge, 2013). Organizational commitment reflects the feelings of an employee to the organization of which involvement, identification and loyalty (Manetje \& Martins, 2009). Organizational commitment with regard to bond a person's psychological to the organization, including work engagement, loyalty and a sense of confidence in the values of the organization (O'Reilly, 1989). According to Mowday et al., (1979), Organizational commitment showed a strong desire of employees to remain within the organization, trying to conform to the wishes of the organization and the belief in accepting the values and goals of the organization. According to Robbins and Judge (2013), organizational commitment is a situation where an individual siding organization and objectives and the desire to maintain membership in the organization. From these several definitions, it can be concluded that organizational commitment is the attitude of employees who have a strong desire to keep working in the organization and try hard to adjust or realize the desires and goals of the organization.

Organizational commitment is a condition where organizational members are bound by actions and beliefs that underlie their activities and involvement in the organization, in turn organizational commitment tends to create a workforce that is committed to work and is responsible (Miller \& Lee, 2001). Many researchers cite the concept of organizational commitment Allen \& Meyer (1990), that the attitude of employee commitment to work varies between individuals, because each individual feels a different commitment to the organization. Organizational commitment is conceptualized as a multidimensional paradigm consisting of three types, namely affective commitment (related to the attitude of wanting to stay), continuance commitment (related to persistence because they need it), and normative commitment (related to the desire to remain in the organization because they feel compelled to do so). Porter et al., (1974) suggested a more empirical measurement of the concept of organizational commitment, that the three main components of organizational commitment, namely; (1) a strong belief to accept the goals of the organization, (2) a strong will to exert all efforts for the benefit of the organization, and (3) a strong desire to remain in the organization.

- Affective commitment. This commitment relates to the emotional attachment of employees and emotionally feeling themselves integrated into the organization. According to Mowday et al. (1979), three 
aspects that together form affective commitment: a) strong belief in the goals and values of the organization and employee acceptance of them, b) readiness to provide support to the organization, and c) needs employees to maintain their membership in the organization. Thus, employees who have a strong affective commitment will continue to work in the organization because they really want to do so.

- Normative commitment . This commitment relates to the feeling of being obliged to continue to work in the organization, individual attachment reflects a moral and ethical obligation to the organization. Employees who have high normative commitment feel that they are ought to remain in the organization. Employee behavior is always based on beliefs about "what is right" and is related to moral issues.

- Continuous commitment. This commitment shows that there is a consideration of profit and loss in employees related to the desire to continue working or even leave the organization. This commitment results from the motivation to avoid future costs associated with possible changes that will occur (e.g. relocation, loss of salary, loss of personal contact with employees). The higher the commitment of employees, the greater the employees feel the cost of change due to loss so that they still want to stay in the organization. Continuous commitment is consciousness will impossibility choose other social identities alternative or other behavior because of the threat will be a huge loss. Employees who mainly work based on this continuance commitment stay in the organization because they need to do this because they have no other choice.

\subsection{Organizational Culture on Employee Commitment}

The success of the organization in achieving the goals determined by the organizational capabilities creates positive attitudes and behavior of employees towards the organization (Aarons \& Sawitzky, 2006; Robbins, 2006). According to Robbins (2006), the important attitudes and behaviors created in organizations include employee organizational commitment. Miller(2003) states that an employee's organizational commitment shows the extent to which an employee is willing to maintain membership because of their interests and associations with organizational goals and values. Mowday et al., (1979) asserted that an employee who is committed to the organization will tend to use extensive personnel on behalf of the organization and strong aspirations to maintain his organizational membership. Committed employees are those who remain in the organization, so companies that have committed employees will be an additional advantage for the organization (Stella, 2012).

Organizational culture is an important characteristic of the organization that affect the creation of a positive attitude of employees to work in the organization (Robbins, 2006; Aarons \& Sawitzky, 2006). Positive attitude is needed and should be owned by every employee within the organization including; organizational commitment attitude. To form positive attitudes of employees, a culture role is needed as a mechanism to guide and shape employee attitudes and behavior (Robbins, 2006). Organizational culture includes standards and norms that regulate the attitude and behavior of employees in organizations (Martins \& Martins, 2003). Even organizational culture acts as an antecedent to the emergence of organizational commitment attitudes (Allen \& Meyer, 1990). The result study by Mahayasa (2018) has proven that there is a relationship between organizational culture and employee organizational commitment. Furthermore, a recent study from Jigjiddorj et al., (2021) find that a strong organizational culture, better able to retain committed employees are high on the job and the organization.

\subsection{Organizational Culture on Employee Involvement}

Employee involvement is a process of employee participation in the work given to realize organizational success. Employee involvement is a factor that can contribute greatly to the company's success in achieving its goals. According to Sridevi \& Markos (2010), employees who are involved indicate that they are emotionally attached to the organization, are involved in work and have great enthusiasm for the company's 
success, and strive to work harder to advance the organization. Robbins (2006) relates organizational culture to employee involvement, that the application of a strong organizational culture is a determining factor for the emergence of positive attitudes and employee involvement towards work.

Companies that are able to build a strong organizational culture in all employees mean that most employees apply the same values in attitudes and behavior, so that employees feel a sense of mutual respect, maintain employee behavior in accordance with the interests of the company and can transmit work spirit to other employees. Furthermore, the application of culture prevailing in the organization of course will affect the extent to which employees feel involved in the work for the survival of the organization.

Research by Njuguna (2016), Nurcholis \& Budi (2019) and Wiley \& Lucas (2020) proves that organizational culture affects employee engagement, the stronger or better the organizational culture applied, the higher employee involvement, and vice versa if the organizational culture is not good then employee engagement on work is getting lower. Organizational culture is a factor that encourages the involvement of employees in the company (Al Shehri et al., 2017; Lockwood, 2007).

\subsection{Employee Involvement on Organizational Commitment}

Employees with high involvement have a positive attitude towards work and will be involved in achieving organizational goals or doing something to achieve company goals. The involvement of employees in line with the commitment of the organization, the employees involved to work have the attitude of employees' organizational commitment y ang better, and vice versa low or careless employee engagement will be followed by a low organizational commitment as well. The results study by Phipps et al., (2013) revealed that employee involvement has a significant positive effect on organizational commitment. Sutiyem et al., (2020) that employee involvement has a positive and significant effect on the organizational commitment of banking employees.

Study by Rameshkumar (2020), said that employee engagement is positively related to affective and normative component while the engagement was not significantly associated with continuity component of organizational commitment. Schaufeli \& Bakker (2004) revealed that there is an optimistic relationship between engagement and organizational commitment. Martin et al., (1995) research results reveal that employees who are members of employee engagement programs have a significant influence on higher organizational commitment than employees who are not members. Hanaysha, (2016) and Anindita \& Seda (2018) prove that employee involvement has a positive effect on organizational commitment, employees with high involvement tend to have high organizational commitment. Employees who have a positive mindset tend to reflect a positive attitude towards work, and appear to have greater affective and normative commitment. The results of this study had previously been predicted by Allen \& Meyer (1990) that employee engagement has a positive relationship with affective and normative commitment and a negative relationship with continuity commitment.

Tumbelaka et al., (2016), indirectly organizational culture has a significant positive effect on organizational commitment mediated by job satisfaction. This means that a strong organizational culture that can be accepted and run well by employees will increase employee job satisfaction, which in turn can increase employee organizational commitment. The results of the analysis of the direct influence of organizational culture on the desire to leave are not significant, but have a significant negative indirect effect on the desire to leave through organizational commitment as a variable that mediates the relationship. 


\section{Conceptual Framework and Hypothesis}

The following conceptual framework that is used can be seen below:

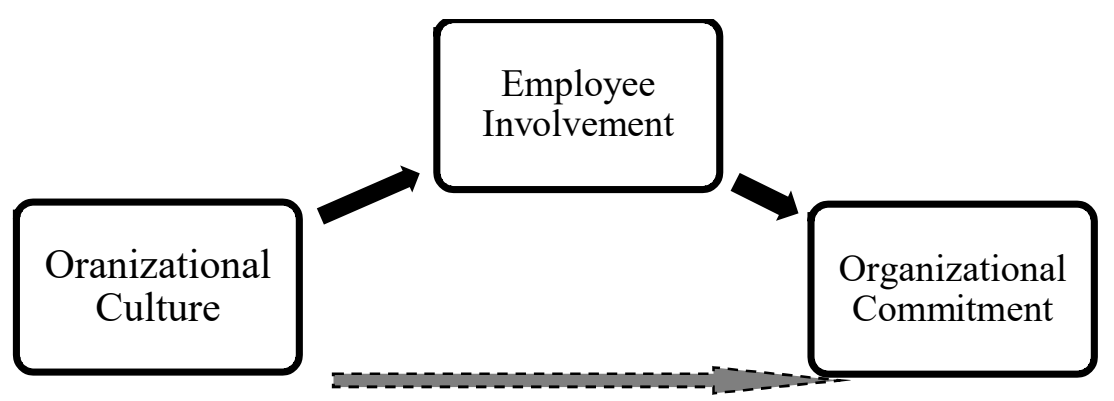

\section{Hypothesis}

Fig 1. Conceptual Framework

Based on the theoretical and conceptual framework that have been described previously, the research hypotheses can be formulated as follows:

H1: Organizational culture has a significant effect on organizational commitment .

$\mathrm{H} 2$ : Organizational culture has a significant effect on employee involvement.

H3: Employee involvement has a significant effect on organizational commitment

H4: Organizational culture through employee involvementt has a significant and positive effect to employee organizational commitment.

\section{METHODS}

The research method uses a quantitative approach with the type of explanatory research, this can be seen from the research objective, namely to explain the relationship between organizational culture variables as independent and employee involvement as an intervening variable, and employee organizational commitment variable as the dependent variable. From these research variables, research indicators are derived and then from indicators are derived into research instruments.

The object of research is one of the largest maternity hospitals in Pekanbaru city. The population or the object of the research are nurses, who work in the Maternity Hospital (initial the hospital is "EB") totaling 135 people. According to Arikunto, (2010), if the population is less than or equal to 100, it is recommended to take the whole population, while the population is above 100 , the sample is taken $10 \%-15 \%$ or $20 \%-25 \%$ of the population. For the purposes of data analysis, the sample size was set at $50 \%$ or 67 using purposive sampling technique. The characteristics of the selected sample members are medical employees who have worked for more than 3 years.

Collected data using a questionnaire technique to respondents from medical employees or nurses. The reasons that are considered for using this questionnaire are the limited time for medical employees to be interviewed, and as professionals it is easy to understand the substance of the statements in the questionnaire. Data collected from respondents include; organizational culture, employee involvement and organizational commitment of medical employees. The data analysis in this study is descriptive statistics and data analysis using Smart-PLS software. 


\section{RESULT}

\subsection{Evaluation of Measurement Model (Outer Model)}

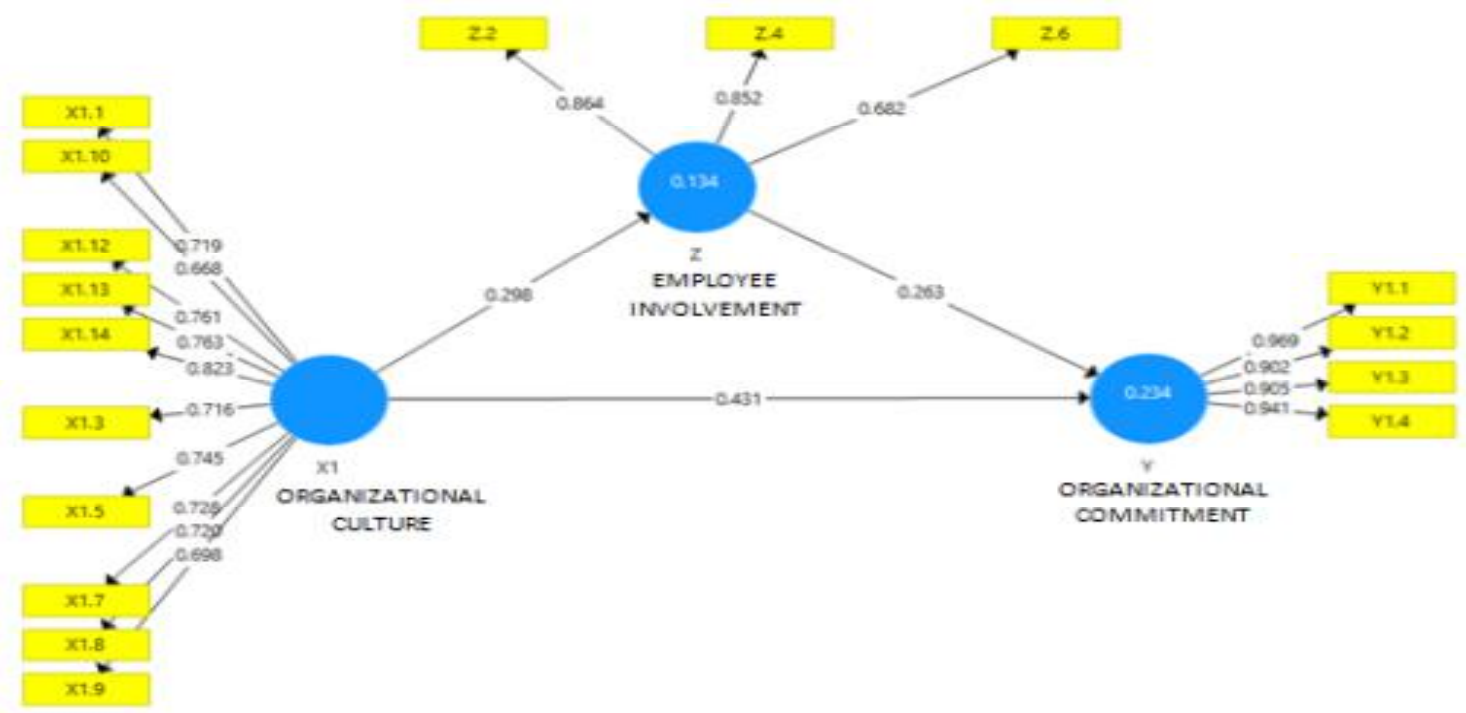

Fig 2. Outer Model

\section{Convergent Validity}

Convergent validity (the magnitude of the loading factor value for each construct) of the measurement model with the indicator reflective model is assessed based on the correlation between the item score/component score and the construct score calculated by PLS. The rule of thumb, which is usually used to assess the loading factor, should be $>0.7$ for confirmatory research and the loading factor value between $0.6-0.7$ is still acceptable for exploratory research. Furthermore, for the construct and measurement scale development stage or research instrument development, a loading factor value of 0.5 is considered sufficient (Hair et al., 2009; Ghozali, 2017). Sometimes the results of the analysis of the reliability indicator show a value that is low or less than the standard above, then the researcher then drops the item (indicator) to get a fit model.

Table 1. Indicator and Value of Loading factor

\begin{tabular}{c|c|c|c}
$\begin{array}{c}\text { Variable/ } \\
\text { Indicator }\end{array}$ & $\begin{array}{c}\text { Organizational } \\
\text { culture } \\
\text { (X1) }\end{array}$ & $\begin{array}{c}\text { Organizational } \\
\text { Commitment } \\
\text { (Y) }\end{array}$ & $\begin{array}{c}\text { Employee Involvement } \\
\text { (Z) }\end{array}$ \\
\hline $\mathrm{X} 1.1$ & 0.719 & & \\
\hline $\mathrm{X} 1.10$ & 0.668 & & \\
\hline $\mathrm{X} 1.12$ & 0.761 & & \\
\hline $\mathrm{X} 1.13$ & 0.763 & & \\
\hline $\mathrm{X} 1.14$ & 0.823 & & \\
\hline $\mathrm{X} 1.3$ & 0.716 & & \\
\hline $\mathrm{X} 1.5$ & 0.745 & & \\
\hline $\mathrm{X} 1.7$ & 0.728 & & \\
\hline $\mathrm{X} 1.8$ & 0.720 & & \\
\hline $\mathrm{X} 1.9$ & 0.698 & & \\
\hline $\mathrm{Y} 1.1$ & & 0.969 & \\
\hline $\mathrm{Y} 1.2$ & & 0.902 & \\
\hline $\mathrm{Y} 1.3$ & & 0.905 & \\
\hline $\mathrm{Y} 1.4$ & & 0.941 & \\
\hline & & &
\end{tabular}




\begin{tabular}{c|c|c|c} 
Z.2 & & & 0.864 \\
\hline Z.4 & & & 0.852 \\
\hline Z.6 & & & 0.682
\end{tabular}

Source: PLS Processed data, 2021

Based on table 1 above, it can be seen that the indicator variables for Organizational Culture X), Nurse involvement $(\mathrm{Z})$ and Organizational Commitment $(\mathrm{Y})$ have an outer loading value $>0,6$ meaning the indicator meets convergent validity and after removing the indicator variable which has an outer loading below $<0,6$, so that this indicator is considered reliable to measure the research construct.

\section{Discriminant Validity}

After finishing measuring the outer loading to assess convergent validity, then measurements were made to measure the second outer model, discriminant validity. One way to measure the outer model with discriminant validity is based on the cross loading value. The cross loading value shows the magnitude of the correlation between each research construct and its indicators and indicators from other block constructs. A measurement model has good discriminant validity if the correlation between the construct and its indicators is higher than the correlation with indicators from other block constructs. The cross loading results obtained from data processing using SmartPLS 3.0 are as shown in the following table.

Table 2. Cross Loading Results

\begin{tabular}{l|r|r|r}
\hline $\begin{array}{l}\text { Indicator } \\
\text { Variable }\end{array}$ & $\begin{array}{c}\text { Organizational } \\
\text { culture } \\
(\mathbf{X})\end{array}$ & $\begin{array}{c}\text { Organizational } \\
\text { Commitment } \\
(\mathbf{Y})\end{array}$ & $\begin{array}{c}\text { Employee } \\
\text { Involvement } \\
(\mathbf{Z})\end{array}$ \\
\hline $\mathrm{X} 1.1$ & $\mathbf{0 . 7 1 9}$ & 0.039 & -0.063 \\
\hline $\mathrm{X} 1.10$ & $\mathbf{0 . 6 6 8}$ & 0.122 & 0.063 \\
\hline $\mathrm{X} 1.12$ & $\mathbf{0 . 7 6 1}$ & 0.504 & -0.103 \\
\hline $\mathrm{X} 1.13$ & $\mathbf{0 . 7 6 3}$ & 0.256 & -0.227 \\
\hline $\mathrm{X} 1.14$ & $\mathbf{0 . 8 2 3}$ & 0.411 & -0.040 \\
\hline $\mathrm{X} 1.3$ & $\mathbf{0 . 7 1 6}$ & 0.115 & -0.019 \\
\hline $\mathrm{X} 1.5$ & $\mathbf{0 . 7 4 5}$ & 0.152 & -0.024 \\
\hline $\mathrm{X} 1.7$ & $\mathbf{0 . 7 2 8}$ & 0.211 & -0.052 \\
\hline $\mathrm{X} 1.8$ & $\mathbf{0 . 7 2 0}$ & 0.025 & -0.035 \\
\hline $\mathrm{X} 1.9$ & $\mathbf{0 . 6 9 8}$ & 0.126 & 0.114 \\
\hline $\mathrm{Y} 1.1$ & 0.428 & $\mathbf{0 . 9 6 9}$ & 0.208 \\
\hline $\mathrm{Y} 1.2$ & 0.357 & $\mathbf{0 . 9 0 2}$ & 0.195 \\
\hline $\mathrm{Y} 1.3$ & 0.344 & $\mathbf{0 . 9 0 5}$ & 0.231 \\
\hline $\mathrm{Y} 1.4$ & 0.377 & $\mathbf{0 . 9 4 1}$ & 0.195 \\
\hline $\mathrm{Z} .2$ & -0.057 & 0.220 & $\mathbf{0 . 8 6 4}$ \\
\hline $\mathrm{Z} .4$ & -0.097 & 0.198 & $\mathbf{0 . 8 5 2}$ \\
\hline $\mathrm{Z} .6$ & -0.085 & 0.043 & $\mathbf{0 . 6 8 2}$ \\
\hline $\mathrm{S} 04 \mathrm{~s}$ & & &
\end{tabular}

Source: PLS Processed data, 2021

Based on the data in table 2 above, it is known that the correlation value of the construct with its indicators shows a higher number than the correlation value with other constructs. These results indicate that all latent constructs or variables in this research model already have good discriminant validity. Another way to assess discriminant validity other than the cross loading value is the average extracted (AVE) value. The discriminant validity model is good if the AVE value of each construct is $>0.50$ (Hair et al., 
2009; Ghozali, 2017) From table 3 it can be seen that the AVE value is $>0.50$, this means that all constructs or latent variables in this research model have has good discriminant validity .

Table 3. AVE Value

\begin{tabular}{|l|c|}
\hline & Average Extracted Variance (AVE) \\
\hline X1_Organizational Culture & 0.541 \\
\hline Y_Organizational & 0.864 \\
Commitment & \\
\hline Z_Employee Involvement & 0.646 \\
\hline
\end{tabular}

Source: PLS Processed data, 2021

\section{Composite Reliability}

In addition to the validity test, the measurement of this model is also carried out to test the reliability of a construct. The reliability test was carried out to prove the accuracy and consistency of a construct. The assessment that is usually used to assess construct reliability and is declared reliable if the composite reliability and Cronbach alpha values are above 0.70 for confirmatory research and $0.60-0.70$ are still acceptable for exploratory or investigative research.

The reliability test was carried out to test and prove the accuracy, consistency and accuracy of the instruments used in measuring the constructs. To measure the reliability of a construct with formative indicators can be done in two ways, namely with composite reliability and Cronbach alpha. Construct reliability by using reflexive indicators is carried out with composite reliability. The value of composite reliability is usually used a value greater than 0.7 for the limitation regarding the Cronbach alpha score must be greater than 0.6 . From the results of data processing using smartPLS can be seen in Table 4 below.

Table 4. Construct Reliability Value

\begin{tabular}{|l|c|c|c|}
\hline & Cronbach's Alpha & rho_A & Composite Reliability \\
\hline $\begin{array}{l}\text { X1_Organizational } \\
\text { Culture }\end{array}$ & 0.929 & 0.998 & 0.921 \\
\hline $\begin{array}{l}\text { Y_Organizational } \\
\text { Commitment }\end{array}$ & 0.947 & 0.952 & 0.962 \\
\hline $\begin{array}{l}\text { Z_Employee } \\
\text { Involvement }\end{array}$ & 0.749 & 0.805 & 0.844 \\
\hline
\end{tabular}

Source: PLS Processed Data, 2021

Based on the results of data processing using smartPLS, the composite reliability value for organizational culture variables, employee involvement and nurse organizational commitment was $>0.7$ and Cronbach's alpha value was $>0.6$. It means that all variables in the research model have a high level of reliability.

\subsection{Evaluation of Inner model (Structural Model)}

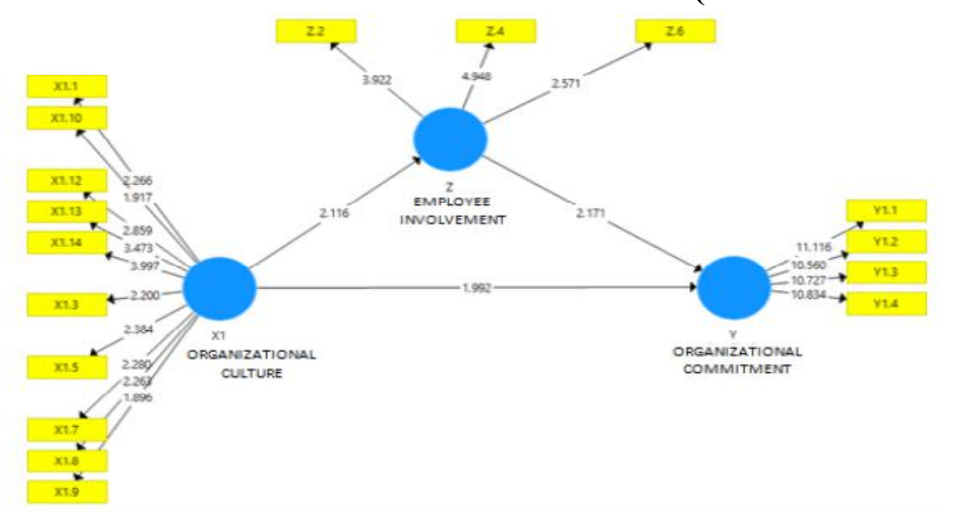

Fig 3. SmartPLS Result Model 


\section{Coefficient Determination $\left(R^{2}\right)$}

Coefficient determination (R-Square) is used to measure how big the influence of variable latent exogenous particular against endogenous latent variables. Rated R Squares is the result of linear regression which is the amount of endogenous variability that is able to be explained by exogenous variables.

Chin (1998; in Ghozali, 2017) mentions the value of R2 of 0.67 to above shows the structural model that describes the influence of exogenous variables on endogenous variables including category stronger, if the result R2 of $0.33-0.67$ showed moderate and if the result of $0.19-0.33$ categorized weak and if the value of R2 under 0.19 shows structural models do not have the strength.

Table 5. R-Square Value

\begin{tabular}{|l|c|c|}
\hline \multicolumn{1}{|c|}{ Structural Model } & R-Square & Adjusted R Square \\
\hline $\begin{array}{l}\text { Y_K Organizational } \\
\text { commitment }\end{array}$ & 0.234 & 0.210 \\
\hline Z_K Employee involvement & 0.134 & 0,129 \\
\hline
\end{tabular}

Source: PLS Processed Data, 2021

- The results of path analysis is obtained value of R-Square $\left(\mathrm{R}^{2}\right)$ variable involvement of employees (nurses) amounted to 0.134 , the value of $\mathrm{R}^{2}$ is showing a model of structural it does not have the strength.

Rated $\mathrm{R}^{2}$ is significantly variable construct the involvement of employees (nurses) can be explained influence by cultural organizations by $13.40 \%$ or strength of the effect of cultural organizations on the involvement of employees is very weak and the rest of $86.60 \%$ is influenced by variables other outside the model of research.

- From the results of the analysis of pathways obtained value of $\mathrm{R}^{2}$ for variable commitment to the organization of 0.234 , and the figure is categorized influence of the weak against the commitment of the organization.

This means that the variability of the construct of the organizational commitment can be explained influence by the variability of cultural organizations and the involvement of nurses by $23,40 \%$ and the remaining $76.60 \%$ is explained by variables other outside the model of research.

\section{Hypothesis testing}

In testing the hypothesis, this study uses several criteria that must be met, namely the original sample, $t$ statistics, and p-values. The original sample value is used to see the direction of hypothesis testing, if the original sample shows a positive value, it means the direction is positive, and if the original sample value is negative, it means the direction is negative. Then t-statistics are used to show the significance. To test using t-statistics, it must be known whether the hypothesis has a direction or not.

If the hypothesis has a direction (one-tiled), then the t-statistics value must be $>1.64$, and if the hypothesis has no direction (two-tiled) then the t-statistic value must be $>1.96$. Because in this study built around the hypothesis that $t$ idak own direction (one-tiled), then that hypothesis can be accepted value of its t-statistics should be $>1.96$. Then the last is p-values, this criterion is also used to test the significance of a result . In this study, the p-values that must be achieved so that a hypothesis can be accepted are $<5 \%$ or $<0.05$. To be ab le to say that a hypothesis can be accepted, then these criteria must be met.

Table 6 . Path Coefficient - Bootstrap

\begin{tabular}{|l|l|c|c|c|c|c|}
\hline & $\begin{array}{c}\text { Original } \\
\text { Sample } \\
(\text { O) }\end{array}$ & $\begin{array}{c}\text { Standard } \\
\text { Deviation } \\
\text { (STDEV) }\end{array}$ & $\begin{array}{c}\text { T Statistics } \\
\text { (O/STDEV) }\end{array}$ & P Values & Results \\
\cline { 1 - 2 } & Direct Influence: & & & \\
\hline
\end{tabular}




\begin{tabular}{|l|l|c|c|c|c|c|}
\hline Hipotesa 1. & $\begin{array}{l}\text { Organizational } \\
\text { Culture (X) - } \\
\text { > Organizational } \\
\text { Commitment (Y) }\end{array}$ & 0.431 & 0.217 & 1,992 & 0.047 & Accepted \\
\hline Hipotesa 2. & $\begin{array}{l}\text { Organizational } \\
\text { Culture (X) } \\
\text { Employee } \\
\text { Involvement (Z) }\end{array}$ & 0.298 & 0.203 & 2,116 & 0.038 & Accepted \\
\hline Hipotesa 3. & $\begin{array}{l}\text { Employee } \\
\text { Involvement (Z) -> } \\
\text { Employee } \\
\text { Commitment (Y) }\end{array}$ & 0.263 & 0.121 & 2,171 & 0.030 & Accepted \\
\hline Hipotesa 4. & $\begin{array}{l}\text { Organizational (X) } \\
\text { Culture (X) } \\
\text { Employee } \\
\text { Involvement (Z) } \\
\text { Organizational } \\
\text { Commitment (Y) }\end{array}$ & 0,247 & 0.257 & 1,943 & 0.053 & Rejected \\
\hline
\end{tabular}

Source: PLS Processed Data, 2021

- The results of the SEM analysis show the path coefficient of the influence of organizational culture (X) on organizational commitment (Y)) of 0.431 and the T-statistical value of $1.992>1.96$ or the probability value ( $\mathrm{P}$ value) $<0.05$, meaning $\mathrm{H} 1$ is accepted. Thus, it means that there is a significant and positive influence of organizational culture on employee involvement directly. These results conclude that the application of a stronger organizational culture among nurses can raise the pride and perseverance of nurses in completing work in hospitals.

- The results of the SEM analysis show the path coefficient of the influence of organizational culture on the involvement of nurse employees is 0.298 and the T-statistic value is $2.116>1.96$ or $\mathrm{P}$ value $<0.05$, meaning $\mathrm{H} 2$ is accepted. It is proven that there is a significant and positive influence of organizational culture on the involvement of nurse employees. The application of a strong culture among nurses can evoke a proud attitude towards work and full seriousness to carry out work in this hospital.

- The results of SEM analysis show the path coefficient of the influence of employee (nurse) involvement on nurses' organizational commitment is 0.263 and the T-statistic value is $2.171>1.96$ or $\mathrm{P}$ value $<0.05$, meaning $\mathrm{H} 3$ is accepted. It is proven that employee involvement in the work carried out can significantly and positively affect the attitude of organizational commitment. Nurses who have a sense of pride and are ready to work externally can generate positive attitudes towards hospitals, including wanting to stay afloat and feel obliged to advance the hospital.

- The results of the path coefficient analysis of the influence of organizational culture on organizational commitment through the involvement of nurses obtained a number of 0.247 and a T-statistic value of $1.943<1.96$ or $\mathrm{P}$ value $>0.05$, meaning $\mathbf{H 4}$ is rejected. In conclusion, the influence of organizational culture variables is not significant on organizational commitment through employee involvement, but the effect is weak. This means that the indirect effect of organizational culture on organizational commitment is lower than the direct influence of organizational culture on organizational commitment, which is only 0.247 while the direct effect is 0.431 . 


\section{DISCUSSION}

\subsection{Effect of Organizational Culture on Organizational Commitment}

The results of the study conclude that there is a direct influence of organizational culture on organizational commitment, with a path coefficient of 0.431 . This means that when there is a change in the strength of the application of organizational culture in hospitals and other variables are assumed to be fixed, it will result in a nurse's organizational commitment of 0.431 . The attitude of nurses who want to stay in the hospital and even feel responsible for achieving the hospital's business goals, most of them have and apply organizational cultural values as guidelines for forming attitudes and behaviors that are in accordance with the needs of carrying out medical duties in hospitals.

All members of the hospital organization do not behave in a value-free because all members of the nurses arranged and directed by organizational culture (Manetje \& Martins, 2009). Nurses who apply the value of organizational culture has a creative attitude and dare to make decisions and value orientation to result, tend to evoke a sense of proud to work in the hospital and desire and feel obliged to stay working in this hospital. These results are in line with the opinions Mowday et al., (1979) which revealed that an employee who is committed to the organization will tend to employ it extensively for the benefit of the organization and a strong aspiration to maintain a membership organization. The results of this study support previous research conducted by O'Reilly, et al., (1991) and Manetje \& Martins (2009) that employees who work in a strong organizational culture feel more committed to the organization than those who work in a weak culture. Mahayasa (2018) reveals a relationship between organizational culture and employee organizational commitment. Jigjiddorj et al., (2021) said that a strong organizational culture is better able to retain employees who are highly committed to their work and organization.

\subsection{Effect of Organizational Culture on Nurse Involvement}

Employee involvement is a positive attitude of employees towards the work given to realize the success of the organization. Employee involvement will result in attitudes which support the organization to realize the objectives n yes, including the attitude of hard work and great enthusiasm for the benefit of the organization (Sridevi \& Markos, 2010). To achieve employee involvement to the work required a strong values to guide behavior through the application of organizational culture strong. Robbins (2006) results prove that the implementation of organizational culture and sigifikan positive effect on employee involvement (nurse), with a regression coefficient (track) of 0.431 . Nurses who work in this hospital have been equipped and socialized with creative values and courage or aggressiveness and are more oriented to the work team in order to create an orderly, conducive and comfortable work atmosphere for nurses.

This is created when most employees have implemented cultural values in carrying out medical duties or work, so as to create homogeneity of attitudes and behavior of nurses working in hospitals. This regular situation causes a conducive and comfortable work atmosphere. This kind of work environment can evoke the appearance of a nurse's dedication and seriousness towards work. The application of organizational culture that produces uniformity in attitudes and behavior of nurses is a factor that supports and encourages positive attitudes of nurses to involve themselves in the work they do. As in the disclosed Al Shehri et al., (2017) and Lockwood (2007) that organizational culture are factors that encourage employee involvement in the company. The results of this study support previous research conducted by Njuguna (2016), Nurcholis \& Budi (2019) and Wiley \& Lucas (2020) which proved that the application of organizational culture and employee involvement in work within the company, the stronger or better the application of organizational culture among companies employees, the higher the involvement of employees, and vice versa if the application of organizational culture is not good then the involvement of employees to work is getting lower. 


\subsection{Eeffect of Nurse Involvement on Organizational Commitment}

The results showed that the involvement of nurses in the work had an effect on organizational commitment. The involvement of nurses shows a positive attitude towards work, including an attitude of pride and seriousness as well as knocks in order to realize the goals of this hospital. With this positive attitude, it can evoke the attitude of nurses who want to continue to work and survive in the hospital, and are obliged to survive in the hospital organization.

Nurses who have high involvement are found to have nurses who have higher organizational commitment compared to nurses who have low involvement. Likewise, nurses who have low involvement tend to generate low organizational commitment attitudes. The results of this study support previous research conducted by Martin et al., (1995) which revealed that employees who are registered as members of employee engagement programs have higher organizational commitment than non-members, even after being dismissed or dismissed.

The results of this study also support the results of research by Schaufeli et al., (2002); Hanaysha (2016); Anindita \& Seda (2018) and Sutiyem et al., (2020) which conclude that employee engagement has a positive effect on employee organizational commitment.

Employee engagement high mindset and positive attitude towards work is likely to have organizational commitment is also high, specially for component affective and normative.

This study also supports research by Rameshkumar (2020) that employee engagement has a positive effect on affective and continuous commitment, while continuance commitment has no effect. Indeed, long before Allen \& Meyer (1990) have revealed that employee engagement has a positive relationship with affective and normative commitment and a negative relationship with continuity commitment .

\subsection{Effect of Organizational Culture On Organizational Commitment Through Nurse Involvement}

The results of the study found that organizational culture through the involvement of nurses had no significant effect on organizational commitment or it was not proven that there was an indirect effect of organizational culture in hospitals on organizational commitment through the involvement of nurses. The results of this study do not support previous research, such as Tumbelaka et al., (2016) which states that organizational culture has an indirect effect on organizational commitment which is mediated by job satisfaction. The results of this study also do not support the research of Heriyanti (2021) who found that organizational culture has an effect on organizational commitment which is mediated by job satisfaction. According to previous study, a strong and well-implemented organizational culture will increase job satisfaction, and then employee satisfaction can increase nurses' organizational commitment. Employee satisfaction and involvement is an employee's positive attitude towards the work being carried out, the more positive the employee's attitude towards work will result in an employee's organizational commitment attitude (Robbins, 2006)

\section{Conclusion and Recommendation}

\subsection{Conclusion.}

From the results of the study, it has been proven that there is a direct effect of organizational culture on organizational commitment among nurses at the Maternity Hospital, nurses who apply strong organizational cultural values are factors that can lead to and arouse organizational commitment to the hospital, including the attitude of wanting to survive and feel responsible for the provision of medical services in hospitals. Research result prove the influence of organizational culture on the involvement of nurses to work in hospitals. Nurses who have applied the values of creativity and courage to make decisions related to medical actions generate positive attitudes towards work, including being proud to be part of the work and enthusiastic to carry out medical work in hospitals. Furthermore, nurse involvement has also been shown to have an effect on hospital 
organizational commitment. Nurses who are professional in the field of medical care have an attitude of pride and enthusiasm and are enthusiastic about carrying out and completing medical tasks in hospitals, this attitude of involvement can arouse the desire of nurses to continue to work in hospitals and be responsible for the implementation of medical services in hospitals. The results of testing the indirect effect of organizational culture on organizational commitment through the involvement of nurses in hospitals are not proven. The path coefficient of the direct influence of organizational culture on organizational commitment is greater than the indirect effect. The existence of a nurse's attachment variable in this research model has no meaning for the relationship between organizational culture and the organizational commitment of nurses in the hospital.

\subsection{Recommendations}

With the proven direct effect of organizational culture factors on nurses' organizational commitment, it is necessary to suggest to hospital leaders to further improve the application of organizational culture to nurses by streamlining socialization and increasing coaching activities to nurses. The application of organizational culture has an effect on increasing the involvement of nurses in hospitals, the hospital needs to make efforts to increase the application of cultural values comprehensively. Also found evidence of the effect of nurse involvement on organizational commitment in hospitals. To support the involvement of nurses in hospital work, it is necessary to have a more conducive work environment so that nurses are more comfortable working in hospitals. Furthermore, the indirect effect of organizational culture on organizational commitment through employee involvement is not proven, meaning that employee involvement does not give meaning and contribution to the relationship between organizational culture and organizational commitment.

\section{REFERENCES}

[1] Aarons, G. A., \& Sawitzky, A. C. (2006). Organizational climate partially mediates the effect of culture on work attitudes and staff turnover in mental health services. Administration and Policy in Mental Health and Mental Health Services Research, 33(3), 289-301. https://doi.org/10.1007/s10488-006-0039-1

[2] Akbar, M. R. (2013). Pengaruh Budaya Organisasi terhadap Employee Engagement (Studi pada Karyawan PT. Primatexco Indonesia di Batang). Journal of Social and Industrial Psychology, 2(1), 10-18. https://journal.unnes.ac.id/sju/index.php/sip/article/view/2124

[3] Al Shehri, M., McLaughlin, P., Al-Ashaab, A., \& Hamad, R. (2017). The Impact of Organizational Culture on Employee Engagement in Saudi Banks. Journal of Human Resources Management Research, 2017, 1-23. https://doi.org/10.5171/2017.761672

[4] Allen, N. J., \& Meyer, J. P. (1990). The measurement and antecedents of affective, continuance and normative commitment to the organization. Journal of Occupational Psychology, 63(1), 1-18. https://doi.org/10.1111/j.2044-8325.1990.tb00506.x

[5] Anindita, R., \& Seda, E. (2018). How employee engagement mediates the influence of individual factors toward organizational commitment. Problems and Perspectives in Management, 16(1), 276-283. https://doi.org/10.21511/ppm.

[6] Arikunto, S. (2010). Prosedur Penelitian Suatu Pendekatan Praktik. PT. Rineka Cipta. Jakarta.

[7] Dauber, D., Fink, G., \& Yolles, M. (2012). A configuration model of organizational culture. SAGE Open, 2(1), 116. https://doi.org/10.1177/2158244012441482

[8] Fanggidae, T. S., Djani, W., \& M.N.B, N. (2020). Analysis Of The Effect Of Quality Of Work Life And Organizational Culture On Employee Engagement At PT Jasa Raharja (Company) East Nusa Tenggara Branch. International Journal of Economics, Business and Management Research, 4(02), 15-33.

[9] Gamayuni, R. R. (2019). The Effects of budgetary participation, budgetary slack, authority delegation, and organizational commitment on managerial performance on local government in Lampung, Indonesia. Journal of Administrative and Business Studies, 5(6). https://doi.org/10.20474/jabs-5.6.4

[10] Ghozali, I. (2017). Model Persamaan Struktural Konsep Dan Aplikasi Dengan Program AMOS 24. Semarang. Badan Penerbit Universitas Diponegoro.

[11] Hair, J., Black, W., Babin, B., \& Anderson, R. (2009). Multivariate data analysis. Prentice Hall. London. 
[12] Hanaysha, J. (2016). Testing the Effects of Employee Engagement, Work Environment, and Organizational Learning on Organizational Commitment. Procedia - Social and Behavioral Sciences, 229, 289-297. https://doi.org/10.1016/j.sbspro.2016.07.139

[13] Heriyanti, S. S. (2021). Peran Mediasi Kepuasan Kerja pada Pengaruh Budaya Organisasi Terhadap Komitmen Organisasi. Jurnal Ekonomi \& Ekonomi Syariah Vol 4 No 1, Januari 2021, 4(1), 267-277.

[14] Indayati, N. (2012). The Influence of Employee Involvement, Organizational Culture, and Leadership Style on Organizational Commitment in Improving Employee Performance (Study at Brawijaya University). Jurnal Aplikasi Manajemen, 10(2), 344-356. https://jurnaljam.ub.ac.id/index.php/jam/article/viewFile/425/465

[15] Jigjiddorj, S., Zanabazar, A., Jambal, T., \& Semjid, B. (2021). Relationship Between Organizational Culture, Employee Satisfaction and Organizational Commitment. SHS Web of Conferences, 90, 02004. https://doi.org/10.1051/shsconf/20219002004

[16] Kalia, N., \& Verma, Y. S. (2017). Organizational Culture and Employee Engagement: an Interrelationship Study in Hospitality Industry of. International Journal of Human Resource Management and Research (IJHRMR), $7(3), 13-22$.

[17] Kartiningsih, K. (2007). Analisis Pengaruh Budaya Organisasi Dan Keterlibatan Kerja Terhadap Komitmen Organisasi Dalam Meningkatkan Kinerja Karyawan (Studi Pada Pt. Bank Tabungan Negara (Persero) Cabang Semarang). https://core.ac.uk/download/pdf/11717724.pdf

[18] Lockwood, N. R. (2007). Leveraging Employee Engagement for Competitive Advantage: SHRM Research Quarterly, 1, 1-12.

[19] Lok, P., \& Crawford, J. (1999). The relationship between commitment and organizational culture, subculture, leadership style and job satisfaction in organizational change and development. Leadership \& Organization Development Journal, 20(7), 365-374. https://doi.org/10.1108/01437739910302524

[20] Luthans, F. (2006). Perilaku Organisai, Terjemahan (A. Yuwono (ed.)). Penerbit ANDI. https://doi.org/21:302.35

[21] Macey, W. H., \& Schneider, B. (2008). The Meaning of Employee Engagement. Industrial and Organizational Psychology, 1(1), 3-30. https://doi.org/10.1111/j.1754-9434.2007.0002.x

[22] Mahayasa, I. G. A. (2018). Pengaruh Kepuasan Kerja Dan Budaya Organisasi Terhadap Komitmen Organisasional Dan Organizational Citizenship Behavior Perawat. Matrik: Jurnal Manajemen, Strategi Bisnis Dan Kewirausahaan, 73-86. https://doi.org/10.24843/MATRIK:JMBK.2018.v12.i01.p08

[23] Manetje, O., \& Martins, N. (2009). The Relationship Between Organisational Culture and Innovation. Southern African Business Review, 13(1), 87-111.

[24] Martin, C. L., Bennett, N., \& Parsons, C. K. (1995). The Influence of Employee Involvement Program Membership During Downsizing: Attitudes Toward the Employer and the Union. Journal of Management, 21(5), 879-890. https://doi.org/10.1177/014920639502100504

[25] Martins, N \& Martins, E. (2003). Organisational culture. In Organisational behaviour: Global and southern African perspectives (1st ed). Pearson Education Sout Africa.

[26] Maslach, C., Schaufeli, W. B., \& Leiter, M. P. (2001). Job burnout. Annual Review of Psychology, 52(February), 397-422. https://doi.org/10.1146/annurev.psych.52.1.397

[27] Meyer, J. P., \& Allen, N. J. (1991). A three-component conceptualization of organizational commitment. Human Resource Management Review, 1(1), 61-89. https://doi.org/https://doi.org/10.1016/1053-4822(91)90011-Z

[28] Miller, D., \& Lee, J. (2001). The people make the process: Commitment to employees, decision making, and performance. Journal of Management, 27(2), 163-189. https://doi.org/10.1016/S0149-2063(00)00094-5

[29] Miller, K. (2003). Value, attitudes and job satisfaction In Robbins, SP, Odendaal A. \& Roodt, G.(eds), Organisational Behaviour: Global and Southern African Perspectives. Pearson Education South Africa.

[30] Morrison, K. A. (1997). How franchise job satisfaction and personality affects performance, organizational commitment, franchisor relations, and intention to remain. Journal of Small Business Management, 35(3), 39-67.

[31] Mowday, R. T., Steers, R. M., \& Porter, L. W. (1979). The measurement of organizational commitment. Journal of Vocational Behavior, 14(2), 224-247. https://doi.org/10.1016/0001-8791(79)90072-1

[32] Njuguna, R. G. (2016). Influence Of Organizational Culture On Employee Engagement At Kcb Head Office. International Journal of Contemporary Business Studies, 3(11), 46-58.

[33] Nurcholis, G., \& Budi, W. (2019). The Impact of Organizational Culture and Perceived Organizational Support on 
Employee Engagement. Advances in Social Science, Education and Humanities Research, Volume 395, 395, 240 246.

[34] O'Reilly, C. (1989). Corporations, Culture, and Commitment: Motivation and Social Control in Organizations. In California Management Review, 31 (4), 9-25. https://doi.org/10.2307/41166580

[35] O'Reilly, C. A., Chatman, J., \& Caldwell, D. F. (1991). People and organizational culture: a profile comparison approach to assessing person-organization fit. Academy of Management Journal, 34(3), 487-516.

[36] Pawestri, T. S., \& Pradhanawati, A. (2018). Pengaruh Ketidakamanan Kerja, Keterlibatan Karyawan Dan Dukungan Organisasi Terhadap Kinerja Karyawan Dengan Komitmen Organisasional Sebagai Variabel Intervening Pada Karyawan Bagian Produksi Bulu Mata Palsu Pt. Cosmoprof Indokarya Di Kabupaten Banjarnega. Jurnal Administrasi Bisnis, 6(2), 80. https://doi.org/10.14710/jab.v6i2.19394

[37] Phipps, S. T. A., Prieto, L. C., \& Ndinguri, E. N. (2013). Understanding the impact of employee involvement on organizational productivity: The moderating role of organizational commitment. Journal of Organizational Culture, Communications and Conflict, 17(2), 107-120.

[38] Porter, L. W., Steers, R. M., Mowday, R. T., \& Boulian, P. V. (1974). Organizational commitment, job satisfaction, and turnover among psychiatric technicians. Journal of Applied Psychology, 59(5), 603-609., 59(5), 603-609. https://doi.org/https://doi.org/10.1037/h0037335

[39] Rameshkumar, M. (2020). Employee engagement as an antecedent of organizational commitment - A study on Indian seafaring officers. Asian Journal of Shipping and Logistics, 36(3), 105-112. https://doi.org/10.1016/j.ajs1.2019.11.003

[40] Robbins S.P. (2006). Perilaku Organisasi, Edisi Terjemahan. PT. Indeks Kelompok Gramedia.

[41] Robbins S.P and Judge T.A. (2013). Organizational behavior (13th ed.). Prentice Hall.

[42] Saks, A. M. (2006). Antecedents and consequences of employee engagement. Journal of Managerial Psychology, 21(7), 600-619. https://doi.org/10.1108/02683940610690169

[43] Schaufeli, W. B., Salanova, M., Gonzales-Roma, V., \& Bakker, A. B. (2002). The measurement of engagement and burnout: a two sample confirmatory factor analytic approach. Journal Of Happiness Studies 3: 71-92, 2002, 63(2), 5. https://doi.org/10.1103/PhysRevE.63.021114

[44] Schaufeli, W. B., \& Bakker, A. B. (2004). Job demands, job resources, and their relationship with burnout and engagement: A multi-sample study. Journal of Organizational Behavior, 25(3), 293-315. https://doi.org/10.1002/job.248

[45] Shuck, B., \& Wollard, K. (2010). Employee engagement and HRD: A seminal review of the foundations. Human Resource Development Review, 9(1), 89-110. https://doi.org/10.1177/1534484309353560

[46] Sridevi, M. S., \& Markos, S. (2010). Employee Engagement: The Key to Improving Performance Solomon. International Journal of Business and Management, 5(12), 89-96. DOI:10.5539/ijbm.v5n12p89

[47] Stella, N. S. (2012). ORGANISATIONAL CULTURE, EMPLOYEE COMMITMENT, SERVICE QUALITY AND CUSTOMER RETENTION. DISSERTATION. BUSINESS ADMINISTRATION OF MAKERERE UNIVERSTY.

[48] Sutiyem, S., Trismiyanti, D., Linda, M. R, Yonita, R., \& Suheri, S. (2020). The Impact of Job Satisfaction and Employee Engagement on Organizational Commitment. Dinasti International Journal of Education Management And Social Science, 2(1), 55-66. https://doi.org/10.31933/dijemss.v2i1.597

[49] Tumbelaka, S. S. X., Habsji, T. Al, \& Nimran, U. (2016). Pengaruh Budaya Organisasi Terhadap Kepuasan Kerja, Komitmen organisasional dan Intention to Leave (Studi pada Karyawan PT.Bitung Mina Utama). Jurnal Bisnis Dan Manajemen, 3(1), 94-108.

[50] Vukonjanski, J., \& Nikolic, M. (2013). Organizational culture and job satisfaction: The effects of company's ownership structure. Journal of Engineering Management and Competitiveness, 3(2), 41-49. https://doi.org/10.5937/jemc1302041v

[51] Wiley, V., \& Lucas, T. (2020). Measuring The Effect Of Social Networking, Organizational Culture Toward Employee Engagement In Soes Organization: Case Study Of Soes In Indonesia. E-Jurnal Ekonomi Dan Bisnis Universitas Udayana, 9(2), 181-198. doi: 54410-109-143679-6-10-20200629. 